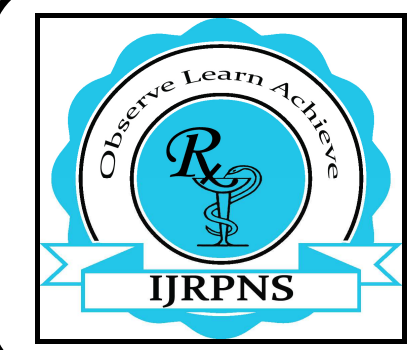

\title{
International Journal of Research in
}

Pharmaceutical and Nano Sciences

Journal homepage: www.ijirpns.com

https://doi.org/10.36673/IJRPNS.2020.v09.i02.A06

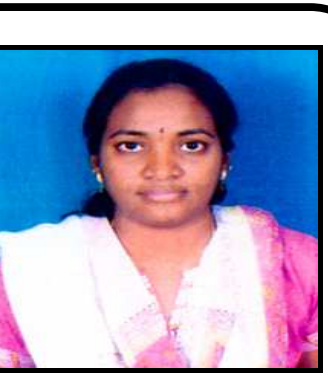

\section{EFFECTIVENESS AND PERCEPTION OF CONCEPT MAPS IN LEARNING ANATOMY AMONG FIRST MBBS STUDENTS}

\author{
Mrudula Chandrupatla*1 \\ 1*Department of Anatomy, Apollo Institute of Medical Sciences and Research, Hyderabad, India.
}

\begin{abstract}
Introduction: Medical education is vast and medical student need to learn how to deal with this information, usable and applicable when providing care to patients. Concept maps is a schematic device for representing a set of concept meanings in a framework of propositions which can be used as a learning tool in a variety of educational setting and provide an opportunity to explore learners' knowledge structures and promote critical thinking and understanding. The student thinks and learns with concepts by linking and chunking new concepts to what they already know. The present study has been planned to know the effect of introducing concept maps as an easy tool in studying anatomy. Methodology: The study is conducted in The Apollo Medical College, Hyderabad for first phase MBBS students of 2018-19 batch in the Department of Anatomy. The teacher conducts a one hour lecture session. The students are divided into 2 groups of 50 each, to one group lecture followed by hand out notes and to other concept maps are given. Post-test is conducted using MCQ'S and the results are compared between the two groups. Results: The MCQ'S result between the two groups is taken and statistical analysis is done using SPSS which is statistically significant. Conclusion: Improvement in learning anatomy is seen and this method makes student thought process more visible and specific. This method of study helps students in self-directed learning to integrate and connect various pieces of information that pertain to the subject.
\end{abstract}

\section{KEYWORDS}

Concepts maps, Self-directed learning and Integration.

\section{Author for Correspondence:}

Mrudula Chandrupatla,

Department of Anatomy,

Apollo Institute of Medical Sciences and Research,

Hyderabad, India.

Email: drmrudula4@yahoo.com

Available online: www.uptodateresearchpublication.com

\section{INTRODUCTION ${ }^{1-5}$}

Medical education includes a vast amount of information. As a medical student they need to learn how to deal with this information so that it is actually usable and applicable when providing care to patients. It is also important for the educators to know about the process of teaching and making learning easy for the students. Centring their attention from 'not on how to teach a given topic' to

March - April 
Mrudula Chandrupatla. / International Journal of Research in Pharmaceutical and Nano Sciences. 9(2), 2020, 33-38.

'what is required for the learner to learn the topic' which is a worthy goal.

Tell me and I forget. Teach me and I remember. Involve me and I learn. Benjamin Franklin

Interactive Teaching is an approach to education developed in the 1980's at Waikato University as part of the Learning in Science Project. It is a means of instructing whereby the teachers actively involve the students in their learning process by way of regular teacher-student interaction, student-student interaction, use of audio-visuals, and hands-on demonstrations. The students are constantly encouraged to be active participants. Understanding and meaning are emphasized, as opposed to mere rote memorization. This facilitates an environment fostering long-term memory retention.

IT techniques for small group

1. Micro teaching/Interactive Teaching

2. Think, pair, and share and Pair-ShareRepeat

3. Journal clubs/Seminars/Pedagogy/Andragogy

4. Brainstorming

5. Buzz session

6. Work placed based assessment

7. Question and Answer sessions

8. Workshops

9. Hands on experiment

10. Forced Debate, Optimist/Pessimist

11. Peer Review Writing Task

12. Psychoanalysis

\section{IT techniques for large group}

- Panel discussion

- Symposium

- Integrated Teaching/Case based/Problem based

- CME's/Conferences-Oral/poster presentations

- Didactic lectures-One-Minute Papers, Muddiest Point

- Jigsaw

- Fish bowl

- Round Robin/Board Rotation

- Pick the Winner

Available online: www.uptodateresearchpublication.com
- Layered Cake Discussion

- Movie Application and TV Commercial

- Question and Answer sessions

- Blender

- Class Modelling

- Simulation

- Group Instructional Feedback Technique

- Audio and Videotaped Protocols

- Google/Facebook/YouTube/Twitter/Blogs

There are various techniques used in interactive teaching. In the present study Concept maps is used as a teaching learning tool and the importance is studied.

Concept maps is a schematic device for representing a set of concept meanings in a framework of propositions (Novak and Gowin; 1984). Concept maps have been used as a learning tool in a variety of educational setting and provide an opportunity to explore learners' knowledge structures and promote critical thinking and understanding. Concept mapping is an instructional strategy for individual and group learning that involves integration of knowledge and creation of meaning by relating concepts. The student thinks and learns with concepts by linking and chunking new concepts to what they already know. This learning with concept maps means that one is making an intentional effort to link differentiate and relate concepts to each other in a hierarchical fashion.

Current trends of instructional strategies followed in Anatomy are the didactic lectures, seminars, tutorial and small group discussions in dissection labs. Medical students are overburdened with vast knowledge and are unable retain the key points.

Therefore the present study has been planned to know the effect of introducing concept maps as an easy tool in studying anatomy

\section{Aim of the Study}

The present study is planned to know the effectiveness of concept maps in learning Anatomy.

\section{Objectives}

- To know the effectiveness of using concept maps in anatomy for First MBBS students.

March - April 
Mrudula Chandrupatla. / International Journal of Research in Pharmaceutical and Nano Sciences. 9(2), 2020, 33-38.

- To assess the perception of students regarding concept maps in First MBBS students.

\section{METHODOLOGY}

- The study is conducted in The Apollo Medical College, Hyderabad for first phase MBBS students of 2018-19 batch in the Department of Anatomy.

- The teacher would conduct a one hour lecture session every week. After the lecture in a topic from Anatomy a Pre-test is conducted to the complete class in the same topic.

- The class would be divided into 2 groups 50 students in each as Control and Study groups.

- After the lecture the teacher would distribute the concept map pertaining to the lecture to only study group.

- After a period of one week Post-test in the form of MCQ'S would be conducted on the same topic for the complete class (100 students).

- The assessment scores of the study group would be statistically compared with the scores of control group.

- If the assessment scores of study group are statistically better than the control group, the control will be introduced to concept mapping.

- We can consider concept maps as a supplementary tool to complement lecture.

- Perceptions of students on concept mapping would be collected through a validated questionnaire.

\section{Questionnaire}

1. The learning objectives of the sessions were achieved.

2. The session is a satisfactory method of learning as compared to traditional one

3. This session has helped in improvement of knowledge

Available online: www.uptodateresearchpublication.com
4. The subject matter or course content was relevant

5. The content was arranged in a logical and clear way.

6. More of such sessions should be planned in regular curriculum of $1^{\text {st }}$ year teaching.

\section{RESULTS AND DISCUSSION \\ Feedback results}

Strongly agree - $60 \%$

Agree - $20 \%$

Neutral - $10 \%$

Disagree - 8\%

Strongly Disagree - 2\%

Medical colleges in India usually following a traditional curriculum, characterized by "discipline wise model" with a high degree of compartmentalization into subjects of basic sciences, preclinical, paraclinical and clinical branches. This leads to unnecessary repetition and confusion in student's mind due to difference of opinion leading to improper grasping of the subject. This discourages students from learning, and they get disinterested in applying knowledge achieved into practice. The method of interactive teaching helps them to involve themselves and imbibe the subjects in detail.

- Increases teacher and learner enthusiasm

- Improving participation and developing techniques are most appropriate to learning goals.

- Encourages critical thinking; fostering selfdirected learning and curiosity; monitoring group progress. 
Mrudula Chandrupatla. / International Journal of Research in Pharmaceutical and Nano Sciences. 9(2), 2020, 33-38.

Example

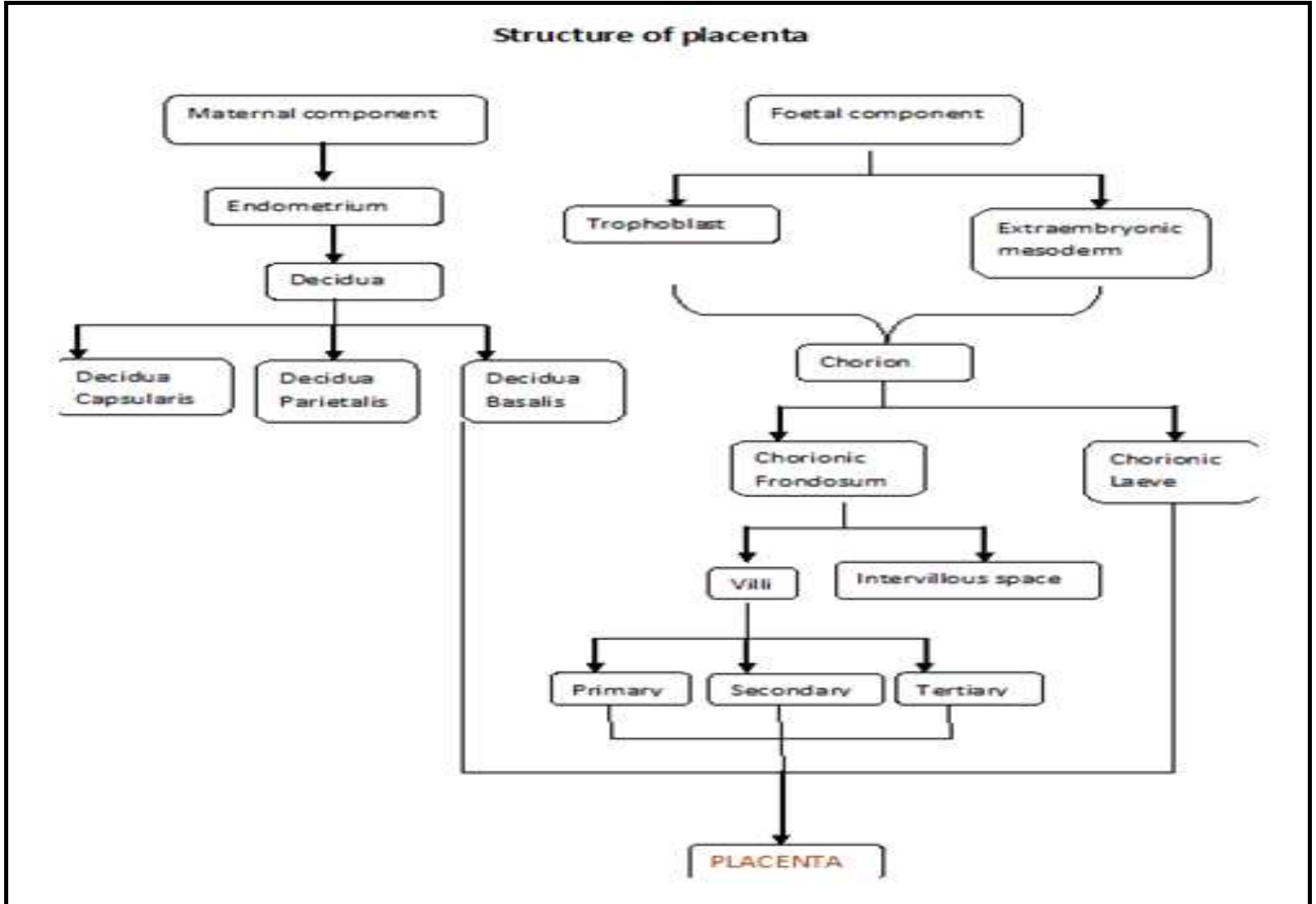

Table No.1: Outcome

\begin{tabular}{|c|c|c|c|c|c|}
\hline \multicolumn{2}{|c|}{ Short term } & \multicolumn{4}{|c|}{$\begin{array}{l}\text { Improvement in learning anatomy } \\
\text { Perception of concept mapping on students } \\
\text { It makes student thought process more visible and specific }\end{array}$} \\
\hline \multicolumn{2}{|c|}{ Intermediate } & \multicolumn{4}{|c|}{$\begin{array}{l}\text { Helps in self-directed learning of the students } \\
\text { Helps students to integrate and connect various pieces of information that pertain to the subject. }\end{array}$} \\
\hline \multicolumn{2}{|c|}{ Long term } & \multicolumn{4}{|c|}{ It can be used to link basic and clinical sciences. } \\
\hline \multicolumn{6}{|c|}{ Table No.2: Outcome Modified Logic Model } \\
\hline \multicolumn{3}{|c|}{ Outcome } & Indicators & Data source & Data collection method \\
\hline 1 & $\begin{array}{l}\text { Si } \\
\text { Studen } \\
\text { in lear }\end{array}$ & $\begin{array}{l}\text { rt term } \\
\text { satisfaction } \\
\text { ng anatomy }\end{array}$ & $\begin{array}{l}\text { Percentage of students in } \\
\text { favour of concept maps }\end{array}$ & Students & Questionnaire \\
\hline 2 & $\begin{array}{l}\text { Int } \\
\text { Enhance } \\
\text { in the }\end{array}$ & $\begin{array}{l}\text { mediate } \\
\text { performance } \\
\text { issessment }\end{array}$ & $\begin{array}{l}\text { Good scores in the } \\
\text { summative assessment }\end{array}$ & Students & Summative assessment \\
\hline 3 & $\begin{array}{r}\mathbf{L} \\
\text { Good } 1 \\
\text { with sci } \\
\text { towa }\end{array}$ & $\begin{array}{l}\text { g term } \\
\text { dical doctor } \\
\text { tific approach } \\
\text { s medical } \\
\text { actice }\end{array}$ & $\begin{array}{l}\text { Improved performance } \\
\text { in clinics }\end{array}$ & Students & $360^{\circ}$ evaluation \\
\hline
\end{tabular}

Available online: www.uptodateresearchpublication.com March - April 
Mrudula Chandrupatla. / International Journal of Research in Pharmaceutical and Nano Sciences. 9(2), 2020, 33-38.

Table No.3: Kirkpatrick Model of Evaluation

\begin{tabular}{|c|c|c|c|c|c|}
\hline S.No & $\begin{array}{c}\text { Levels of } \\
\text { evaluation }\end{array}$ & Evaluation question & Indicators & Data source & $\begin{array}{c}\text { Data collection } \\
\text { method }\end{array}$ \\
\hline 1 & Reaction & $\begin{array}{c}\text { - Do students rate the } \\
\text { concept maps as more } \\
\text { engaging and real learning } \\
\text { experience } \\
\text {-Perception of students on } \\
\text { the effect of concept maps }\end{array}$ & $\begin{array}{c}\text { Number of } \\
\text { positive/negative } \\
\text { marks }\end{array}$ & Students & questionnaire \\
\hline 2 & Learning & $\begin{array}{c}\text { Do students score } \\
\text { significantly better following } \\
\text { concept maps }\end{array}$ & $\begin{array}{c}\text { Difference between the } \\
\text { post test scores }\end{array}$ & Students & Post-test MCQ'S \\
\hline
\end{tabular}

Table No.4: Paired Samples Statistics

\begin{tabular}{|c|c|c|c|c|c|}
\hline S.No & & Mean & N & Std. Deviation & Std. Error Mean \\
\hline 1 & Study Group (With concept maps) & 13.68 & 84 & 3.151 & .344 \\
\hline 2 & Control Group (Without concept) & 9.67 & 84 & 2.538 & .277 \\
\hline
\end{tabular}

Table No.5: Paired Samples Test (According to SPPS VERSION 24)

\begin{tabular}{|c|c|c|c|c|c|c|c|c|c|}
\hline S.No & & \multicolumn{5}{|c|}{ Paired Differences } & \multirow{3}{*}{$\mathrm{T}$} & \multirow{3}{*}{ df } & \multirow{3}{*}{$\begin{array}{l}\text { Sig. (2- } \\
\text { tailed) }\end{array}$} \\
\hline \multirow[t]{2}{*}{1} & \multirow[t]{2}{*}{--} & \multirow[t]{2}{*}{ Mean } & \multirow[t]{2}{*}{$\begin{array}{c}\text { Std. } \\
\text { Deviation }\end{array}$} & \multirow[t]{2}{*}{$\begin{array}{l}\text { Std. Error } \\
\text { Mean }\end{array}$} & \multicolumn{2}{|c|}{$\begin{array}{l}95 \% \text { Confidence } \\
\text { Interval of the } \\
\text { Difference }\end{array}$} & & & \\
\hline & & & & & Lower & Upper & & & \\
\hline 2 & $\begin{array}{l}\text { With - Without } \\
\text { Concept Maps }\end{array}$ & 4.012 & 4.224 & .461 & 3.095 & 4.929 & 8.705 & 83 & .000 \\
\hline
\end{tabular}

\section{TAKE HOME MESSAGE}

- Concept maps are a robust teaching and learning tool

- Concept maps can be used in medical education to link basic and clinical sciences facilitate the development of clinical reasoning and promote interprofessional education.

\section{CONCLUSION}

Use of concept maps in studying Anatomy helps in:

- Improvement in learning anatomy

- It makes student thought process more visible and specific

- Helps in self-directed learning of the students

Available online: www.uptodateresearchpublication.com
- Helps students to integrate and connect various pieces of information that pertain to the subject.

- It can be used to link basic and clinical sciences

\section{ACKNOWLEDGEMENT}

The author wish to express their sincere gratitude to Department of Anatomy, Apollo Institute of Medical Sciences and Research, Hyderabad, India for providing necessary facilities to carry out this research work.

\section{CONFLICT OF INTEREST}

We declare that we have no conflict of interest. 
Mrudula Chandrupatla. / International Journal of Research in Pharmaceutical and Nano Sciences. 9(2), 2020, 33-38.

\section{REFERENCES}

1. Ausubel D P, Novak J D, Hanesian H. Educational psychology: A cognitive view, New York, $2^{\text {nd }}$ Edition, 1986.

2. Daley B and Torren D. Concept maps in medical education: An analytical literature review, Medical education, 44(5), 2010, 440-448.

3. Edmondson K M. Concept mapping for the development of medical curricula, Journal of research in Science teaching, 32(7), 1995, 777-793.

4. Joseph Novak D, Alberto Canas J. The Theory Underlying Concept Maps and How To Construct and Use Them", Institute for Human and Machine Cognition, Accessed, 2006, 24 Nov 2008.

5. Torre D M, Durning S J, Daley B J. Twelve tips for teaching with concept maps in medical education, Med Teach, 35(3), 2013, 201-208.

Please cite this article in press as: Mrudula Chandrupatla. Effectiveness and perception of concept maps in learning anatomy among first MBBS Students, International Journal of Research in Pharmaceutical and Nano Sciences, 9(2), 2020, 33-38. 